\title{
Begal Motor Sebagai Perilaku Menyimpang
}

\author{
Muslim Mappa \\ Fatimah Tola \\ Universitas Muhammadiyah Makassar \\ fatimahtola@unismuh.ac.id \\ Suardi \\ Universitas Muhammadiyah Makassar \\ suardi@unismuh.ac.id
}

\begin{abstract}
ABSTRAK
Penyimpangan adalah konsep masalah sosial berkaitan dengan pelanggaran norma artinya sesuatu itu dianggap sebagai masalah sosial karena menyangkut hubungan manusia dengan nilai nilai dan merupakan gangguan terhadap tujuan kehidupan masyarakat. Tujuan Penelitian yang dilaksanakan merupakan penelitian sosial budayayang Jenis Penelitian yang digunakan adalah metode penelitian deskriptif kualitatif dengan dengan cara penentuan sampel melalui model dan teknik Purposive Samplingdengan memilih beberapa informan yang memiliki kriteria yang telah ditentukan oleh peneliti yakni yang mengetahui tentang Begal motor study kasus perilaku menyimpang di kota makassar. Penelitian ini bertujuan untuk mengetahui eksistensi keberadaan begal motor dan factor-faktor penyebab keberadaan begal motor di kota Makassar. Metode didalam penelitian ini menunjukkan bahwa faktor-faktor yang mempengaruhi adanya begal motor ialah balapan liar menjadi tren,media khususnya gem,filem,sinetron,lemahnya pengawasan social,kondisi perekonomian Negara masih belum cukup baik dan terbatasnya lapangan pekerjaan. Hasil penelitian dapat memberikan kesimpulan memang begalmotor adalah perilaku menyimpang karena tindakannya melukai dan merampok para korbannya secara langsung tanpa memikirkan sebab akibatnya di hari kemudian. Mereka hanya ingin memenuhi kepentingan sesaatnya saja bersama anggota kelompok kelompoknya.
\end{abstract}

Kata Kunci : Begal Motor, Perilaku, Menyimpang Sosial.

\section{PENDAHULUAN}

Penyimpangan adalah konsep masalah sosial berkaitan dengan pelanggaran norma artinya sesuatu itu dianggap sebagai masalah sosial karena menyangkut hubungan manusia dengan nilai nilai dan merupakan gangguan terhadap tujuan kehidupan masyarakat.masalah sosial atau social problems ialah setiap keadaan yang dianggap ancaman bagi masyarakat sebagai suatu keadaan yang tak di kehendaki, tak dapat ditoleransi, atau dianggap ancaman bagi masyarakat .sehingga memerlukan tindakan masyarakat untuk menyelasaikannya.karena aksi pembegalang membutuhkan penanganang yang serius untuk mennggulangi berbagai hal yang tidak di inginkan oleh berbagai masyarakat. Penyimpangan sosial atau perilaku menyimpang, sadar atau tidaksadar pernah kita alami atau kita lakukan.Penyimpangan sosial dapat terjadi 
dimanapun dan dilakukan oleh siapapun. Sejauh mana penyimpangan itu terjadi, besar atau kecil, dalam skala luas atau sempit tentu akan berakibat terganggunya keseimbangan kehidupan dalam masyarakat.Suatu perilaku dianggap menyimpang apabila tidak sesuai dengan nilai-nilai dannorma-norma sosial yang berlaku dalam masyarakat atau dengan kata lain penyimpangan (deviation) adalah segala macam pola perilaku yang tidak berhasil menyesuaikan diri (conformity) terhadap kehendak masyarakat. Penyimpang merupakan sisi negative dari bentuk perilaku positif.karena perilaku positif akan memberikan suasana kenyamanan dan keaamanan bagi masyarakat. Akan tetapi masalah sosial yang kerap terjadi dikota Makassar ialah begal motor yang aksinya merampok dan mencederai korbannya.

\section{LANDASAN TEORI}

Penyimpangan(deviasi)adalah setiap tingka laku yang tak mematuhi norma norma sosial dari suatu kelompok sosial, atau dari suatu masyarakat. ataupun kelakuan yang melanggar ketentuan ketentuan yang di institutikan, yaitu ketentuan yang disepakati sah dalam suatu system sosial.Batasan itu membuat andaian tentang wujudnya suatu integrasi norma, tetapi pada hakekatnya seringkali tak terdapat dalam masyarakat, karena aturan, norma, dan nilai nilai pada kelompok masyarakat yang berlainan akan menyebabkan pandangan tak serupa bagi semua warga masyarakat tersebut. apa yang dianggap menyimpang bagi masyarakat lainnya. Penyimpangan itu timbul dari tindakan untuk mengubah aturan tertentu, Teori merton (1996:156) yang berdasarkan pada konsep anomi(konsep anomi mula mula di kemukakan oleh Durkheim).Keadaan anomi, dan kemudian penyimpangan timbul jika terdapat perbedaan diantara tujuan tujuan sebagaimana ditentukan oleh kebudayaan atau penyimpangan adalah kurangnya peluang guna mencapai tujuan tertentu sesuai dengan norma norma sosial yang berlaku dalam masyarakat itu. Penyebaran tingka laku yang menyimpang itu ditentukan oleh bagaimana upaya yang dianggap syah dalam mencapai tujuan tertentu,tingkat penerimaan tujuan, dan upaya berbagai lapisan dalam masyarakat.Anomi secara umum dapat diartikan sebagai suatu keadaan sosial dalam keterikatan pada aturan aturan normatif sangat lemah. Robert K Merton (1996:157) dalam pembentukan teori anomienya, mengemukakan anomie sebagai suatu keadaan dari struktur sosial dimana terdapat beberapa ketidakserasian antara nilai nilai yang di akui secara budaya dan cara cara yang diakui untuk pencapaian nilai nilaiini.anomi terjadi dimana penekanan yang berlebihan di letakkan pada suatu pilihan dengan mengorbankan yang lain:penekanan pada pencapaian nilai nilai budaya 
mungkin akan menyebabkan orang mengambil dengan cara apaun baik sah maupun tidak. Penekanan ini pada pencapaian tujuan tujuan ekonomi, misalnya mungkin akan cenderung menyebabkan sedikitnya cara-cara yang dipergunakan.bagi beberapa kelompok social,dalam mencapai nilai nilai tertentu sebagai keberhasilan mungkin akan digunakan cara cara yang kurang diterimah secara budaya dari kelompok kelompok lainnya. Teori ini dikembangkan oleh penganut Teori Konflik Karl Marx.Para penganut teori ini berpandangan bahwa kejahatan terkait erat dengan perkembangan kapitalisme.Sehingga perilaku menyimpang diciptakan oleh kelompokkelompok berkuasa dalam masyarakat untuk melindungi kepentingan mereka sendiri.Pandangan ini juga mengatakan bahwa hukum merupakan cerminan kepentingan kelas yang berkuasa dan sistem peradilan pidana mencerminkan nilai dan kepentingan mereka. karena kondisi sosial yang disebabkan oleh tidak meratanya distribusi kekayaan, dan perlakuan yang diskriminasi terhadap kelompok-kelompok masyarakat yang tidak memiliki kekuasaan. Kejahatan yang dilakukan oleh kelas bawah (kriminalitas jalanan): terjadi karena tekanan ekonomi dari masyarakat kelas bawah, dan karena proses alienasi yang mengendorkan ikatan-ikatan sosial di antara para anggotanya.Akses atau kesempatan untuk bertindak kriminal, berbeda-beda berdasarkan kelas sosialnya,kelompok masyarakat bawah jarang terlibat dalam kejahatan yang terorganisir atau kejahatan perusahaan; mereka lebih banyak terlibat dalam kejahatan konvensional/jalanan (perampokan, pembegalan, pencurian, dll).

Teori ini dikemukakan oleh Edwin M. Lemert (1912:12). Menurut teori ini, seseorang menjadi penyimpang karena proses labelling yang diberikan masyarakat kepadanya. Maksudnya adalah pemberian julukan atau cap yang biasanya negatif kepada seseorang yang telah melakukan penyimpangan primer (primary deviation) misalnya pencuri, penipu, pemerkosa, pemabuk, dan sebagainya. Sebagai tanggapan terhadap cap itu, si pelaku penyimpangan kemudian mengidentifikasikan dirinya sebagai penyimpang dan mengulangi lagi penyimpangannya sehingga terjadi dengan penyimpangan sekunder (secondary deviation). Alasannya adalah sudah terlanjur basah atau kepalang tanggung.Pengertian Controlling Menurut Para Ahli George R. Tery (2014:18), mengartikan controllingsebagai mendeterminasi apa yang telah dilaksanakan, maksudnya mengevaluasi prestasi kerja dan apabila perlu, menerapkan tindakan-tindakan korektif sehingga hasil pekerjaan sesuai dengan rencana yang telah ditetapkan. Dale mengatakan bahwa controlling tidak hanya melihat sesuatu dengan seksama dan melaporkan hasil kegiatan mengawasi, tetapi juga mengandung arti memperbaiki dan meluruskannya 
sehingga mencapai tujuan yang sesuai dengan apa yang direncanakan. Robbin menyatakan controlling itu merupakan suatu proses aktivitas yang sangat mendasar, sehingga membutuhkan seorang manajer untuk menjalankan tugas dan pekerjaan organisasi. Admosudirdj (2003:18) mengatakan bahwa pokoknya controlling adalah keseluruhan daripada kegiatan yang membandingkan atau mengukur apa yang sedang atau sudah dilaksanakan dengan kriteria, norma-norma, standar atau rencana-rencana yang telah ditetapkan sebelumnya. Siagian menyebutkan bahwa yang dimaksud dengan controlling adalah proses pengamatan daripada pelaksanaan seluruh kegiatan organisasi untuk menjamin agar semua pekerjaan yang sedang dilakukan berjalan sesuai dengan rencana yang telah ditentukan sebelumnya. Controlling merupakan suatu usaha sistematik untuk menetapkan standar pelaksanaan tujuan dengan tujuan-tujuan perencanaan, merancang system informasi umpan balik, membandingkan kegiatan nyata standar yang telah ditetapkan sebelumnya, menentukan dan mengukur penyimpangan- penyimpangan serta mengambil tindakan koreksi yang diperlukan.langkah-langkah proses pengawasan yaitu :Menetapkan Standar Karena Perencanaan merupakan tolak ukur merancang pengawasan, maka secara logis hal ini berarti bahwa langkah pertama dalam proses pengawasan adalah menyusun rencana. Perencanaan yang dimaksus disini adalah menentukan standar dan Mengukur Kinerja Langkah kedua dalam pengawasan adalah mengukur atau mengevaluasi kinerja yang dicapai terhadap standar yang telah ditentukan. Memperbaiki Penyimpangan Proses pengawasan tidak lengkap jika tidak ada tindakan perbaikan terhadap penyimpanganpenyimpangan yang terjadi. Langkah-langkah proses controlling / pengawasan menurut para ahli. Maman Ukas (2007:13) menyebutkan tiga unsur pokok yang selalu ada dalam proses pengawasan, yaitu : Ukuran-ukuran yang menyajikan bentuk-bentuk yang diminta. Standar ukuran ini bisa nyata, mungkin juga tidak nyata, umum tau khusus, tatapi selama seorang masih menganggap bahwa hasilnya adalah seperti yang diharapkan, Perbandingan antara hasil yang nyata dengan ukuran tadi. Evaluasi ini harus dilaporkan kepada khalayak ramai yang dapat berbuat sesuatu akan hal ini,dan Kegiatan mengadakan koresi. Pengukuran-pengukuran laporan dalam suatu pengawasan tidak akan berarti tanpa adanya koreksi, jikalau dalam hal ini diketahui bahwa aktivitas umum tidak mengarah ke hasil-hasil yang diinginkan.Pandangan dasar teori sosialisasi adalah bahwa penyimpangan sosial merupakan produk dari proses sosialisasi yang kurang sempurna atau gagal.Menurut Albert Bandura dan Richard H. Walters (2003:14) misalnya, anak-anak belajar perilaku menyimpang dengan mengamati dan meniru orang lain yang memiliki perilaku menyimpang. Khususnya, mereka 
mengamati dan meniru orang yang dekat dengannya.Selanjutnya, menurut Capaldi dan Peterson, (2002:8).anak-anak yang agresif umumnya berasal dari keluarga yang orang tuanya terlalu keras dan agresif. Akibatnya, anak kehilangan teladan pengendalian diri dan mungkin menanggapi hukuman dengan meningkatkan agresi. Intinya, perilaku menyimpang dihasilkan oleh proses sosialisasi yang sama dengan perilaku itu.Sementara itu, menurut Mark S. Gaylord dan john F. Galliher serta Edwin Sutherland (2002:15), orang yang memiliki perilaku menyimpang cenderung memiliki ikatan sosial dengan orang lain yang memiliki perilaku menyimpang, dimana orang tersebut mengokohkan norma-norma dan nilai-nilai yang menyimpang. Prinsipnya, setiap kelompok sosial akan mewariskan nilai-nilai dan norma-norma kelompoknya kepada anggota-anggota baru.Kaum muda pada umumnya sangat terbuka terhadap norma, perilaku, dan nilai-nilai yang berasal dari subkultur berbeda, termasuk subkultur perilaku menyimpang. Karena itu, menurut Ronald R. Akers (2013:13) perilaku teman-teman dekat merupakan sarana yang paling baik untuk memprediksi apakah perilaku seorang anak muda sesuai dengan norma yang berlaku ataukah perilaku menyimpang.Teori ini menghubungkan penyimpangan dengan ketidak mampuan untuk menghayati nilai dan norma yang dominan di masyarakat. Ketidakmampuan mungkin disebabkan oleh sosialisasi dalam kebudayaan yang menyimpang.Teori Sosialisasi menyatakan bahwa seseorang biasanya menghayati nilai-nilai dan norma-norma dari beberapa orang yang dekat dan cocok dengan dirinya.Jadi, bagaimanakah seseorang menghayati nilai-nilai dan norma-norma sosial sehingga dirinya dapat melahirkan perilaku menyimpang. Ada dua penjelasan yang dapat di kemukakan. Pertama, Kebudayaan khusus yang menyimpang, yaitu apabila sebagian besar teman seseorang melakukan perilaku menyimpang maka orang itu mungkin akan berperilaku menyimpang juga. Sebagai contoh, beberapa study di Amerika, menunjukkan bahwa di kampung-kampung yang berantakan dan tidak terorganisir secara baik, perilaku jahat merupakan pola perilaku yang normal (wajar). Perilaku menyimpang yang dilakukan oleh seseorang tidak terjadi begitu saja tanpa ada sebab-sebab yang menyertainya, karena perilaku menyimpang berkembang melalui suatu periode waktu-waktu tertentu sebagai hasil dari serangkaian tahapan interaksisosial dan adanya kesempatan untuk berperilaku menyimpang.bolos sekolah.

\section{METODE PENELITIAN}

Penelitian ini termasuk kategori penelitian lapangan (field research) yang berbasis pada tema sosial budaya basis telaah penelitian ini yang terkait dengan sosial budaya 
menyebabkan jenis penelitian yang di pakai adalah penelitian kualitatif. Lokasi penelitian ini di laksanakan di Kota Makassar, Provensi Sulawesi Selatan. Objek dan sasaran data dalam penelitian ini dipilih secara purposive sampling, teknik pengumpulan data yakni; pengamatan terlibat atau observasi, wawancara mendalam, dan pengumpulan data sumber-sumber tertulis atau studi kepustakaan.Untuk memanfaatkan dan mengelola data yang banyak dan padat akan di gunakan teknik analisa deskriptif. Untuk memperoleh keabsahan data, maka peneliti melakukan usaha-usaha yaitu diteliti kredibilitasnya dengan melakukan teknik perpanjangan pengamatan, meningkatkan trianggulasi sumber data menguji kredibilitas ini diartikan sebagai pengecekan data (cek and ricek) dari berbagai sumber dengan berbagai cara dan berbagai waktu. trianggulasi sumber, trianggulasi teknik,

\section{PEMBAHASAN}

Eksistensi keberadaan pembegalan motor di kota makassar hanya bermotif ekonomi. Untuk beberapa kelompok yang umumnya masih remaja, aksi begal sebagai bentuk untuk menunjukkan eksistensi diri.dalam kelompoknya, para remaja akan mudah terpengaruh melakukan hal-hal yang dianggap berani dan konyol. Sekalipun itu berbahaya."Banyak dari mereka (remaja) yang melakukan pembegalan,termotivasi oleh desakan ekonomi. Dengan begitu, eksistensi mereka tetap terjaga dalam pergaulan.Ia mengungkapkan, faktor ekonomi yang menuntut saling unjuk diri karena tidak meratanya ekonomi kelas atas dengan bawah, secara tidak sadar memaksa mereka melakukan tindakan-tindakan yang berbaur konflik yang berujung tindakan kriminalitas. Dari pembahasan di atas sesuai dengan Teori Konflik yang di kembangkan oleh Karl Marx.Para penganut teori ini berpandangan bahwa kejahatan terkait erat dengan perkembangan kapitalisme.Sehingga perilaku menyimpang diciptakan oleh kelompokkelompok berkuasa dalam masyarakat untuk melindungi kepentingan mereka sendiri.Pandangan ini juga mengatakan bahwa hukum merupakan cerminan kepentingan kelas yang berkuasa dan sistem peradilan pidana mencerminkan nilai dan kepentingan mereka.karena kondisi sosial yang disebabkan oleh tidak meratanya distribusi kekayaan, dan perlakuan yang diskriminasi terhadap kelompok-kelompok masyarakat yang tidak memiliki kekuasaan. Kejahatan yang dilakukan oleh kelas bawah (kriminalitas jalanan)

\section{Penyebab adanya Begal Motor}

Penyebab mengapa kejahatan begal motor ada di kota makassar berdasarkan informasi dari masyarakat di kelurahan karunrung yaitu: karena marakmya budaya 
konsumerisme dan materialisme (sepeda motor),serta adanya balapan liar yang harus senantiasa diikuti,serta media, khususnya film Saat ini baik film, sinetron, ataupun permainan banyak yang menampilkan adegan kekerasan secara vulgar yang seolah mengajari penontonnya untuk bisa melakukan hal tersebut,dan lemahnya pengawasan sosial. Satu sama lain saat ini kurang peduli.Sistem keamanan seperti ronda juga sudah jarang yang melakukannya. Sesuai dengan teori Controlling Menurut George R. Tery dengan pembahasan diatas controlling sebagai pengawasan sosial mendeterminasi apa yang telah dilaksanakan, maksudnya mengevaluasi aktivitas dan apabila perlu, menerapkan tindakan-tindakan korektif sehingga hasilnya sesuai dengan rencana yang telah ditetapkan. Dale mengatakan bahwa controlling tidak hanya melihat sesuatu dengan seksama dan melaporkan hasil kegiatan mengawasi, tetapi juga mengandung arti memperbaiki dan meluruskannya sehingga mencapai tujuan yang sesuai dengan apa yang direncanakan. Sehingga tindakan begal mudah diatasi di lingkungan masyarakat karena ada control sosial yang sudah di tetapkan lewat sistem pengamananan pada situwasi malam hari.

\section{Dampak yang di timbulkan Begal Motor}

Menurut masyarakat Karunrung,Selain keresahan ada dampak lain dari maraknya aksi begal motor yang marak belakangan ini.yaitu membuat masyarakat takut beraktivitas pada malam hari karena banyaknya anggota begal motor yang merupakan pelaku aksi begal motor sering gentayangan di tempat tempat yang sunyi dan sepi. Maklum, masyarakat jarang yang mau ambil resiko bepergian di malam hari akhir-akhir ini.Karena sudah banyak aksi pembegalan.dan kebanyakan masyarakat merasa waspada kalau melihat para remaja yang berkumpul ditempat yang sepi.dan terkadang masyarakat beranggapan inilah para pelaku aksi begal motor yang kerap kali melancarkan aksinya. Sesuai dengan teori labeling, Teori ini dikemukakan oleh Edwin M. Lemert (1912:12). Menurut teori ini, seseorang menjadi penyimpang karena proses labelling yang diberikan masyarakat kepadanya. Maksudnya adalah pemberian julukan atau cap yang biasanya negatif kepada seseorang yang telah melakukan penyimpangan primer (primary deviation) misalnya pencuri, penipu, pemerkosa, pemabuk, dan sebagainya. Sebagai tanggapan terhadap cap itu, si pelaku penyimpangan kemudian mengidentifikasikan dirinya sebagai penyimpang dan mengulangi lagi penyimpangannya sehingga terjadi dengan penyimpangan sekunder (secondary deviation). Alasannya adalah sudah terlanjur basah atau kepalang tanggung. 


\section{Solusi Penanggulangan Begal Motor}

Polisi sektor Rappocini harus lebih tegas dalam menangani Pembegalan yang marak terjadi beberapa waktu terakhir ini.membuat Polisi kurang gencar melakukan pengejaran terhadap pelakunya. Polisi bisa menindak begal motor secara lebih luas dan masif. Sayangnya, operasi pemberantasan secara "serius dan besar" seolah baru dilakukan setelah kejahatan itu marak dan betul-betul menebar teror di masyarakat.Selain itu, pemberantasan yang dilakukan bersifat sementara, dalam sebuah operasi berjangka waktu pendek.Operasi seperti itu sifatnya lebih menjadi 'terapi kejut' atau 'shock therapy' dan polisi harus memberikan semacam sosialisasi terhadap remaja yang mayoritasnya anggota begal motor bahwa aksi pembegalan adalah tindakan kriminal yang undang undang peraturannya sudah di tetapkan oleh pemerintah. sebab aturan biasa di langgar, akibat minimnya sosialisasi pihak keamanan Negara dan Efeknya akan menekan angka kejahatan itu untuk selamanya.karena para orang tua juga minim mensosialisasikan terhadap anaknya bahwa begal adalah tindakan yang buruk di mata masyarakat. Sesuai dengan Pandangan dasar teori sosialisasi adalah bahwa penyimpangan sosial merupakan produk dari proses sosialisasi yang kurang sempurna atau gagal.Menurut Albert Bandura dan Richard H. Walters (2003:14) misalnya, anak-anak belajar perilaku menyimpang dengan mengamati dan meniru orang lain yang memiliki perilaku menyimpang. Khususnya, mereka mengamati dan meniru orang yang dekat dengannya.

\section{KESIMPULAN}

1. Eksistensi perbuatan pembegalan motor di kota makassar bukan hanya bermotif ekonomi. Untuk beberapa kelompok yang umumnya masih remaja, aksi begal sebagai bentuk untuk menunjukkan eksistensi diri.mengatakan, dalam kelompoknya, para remaja akan mudah terpengaruh melakukan hal-hal yang dianggap berani. Sekalipun itu berbahaya."Banyak dari mereka (remaja) yang melakukan pembegalan, tidak termotivasi oleh desakan ekonomi.Mereka hanya ikut-ikutan atau membantu temannya dalam melakukan aksi begal.Dengan begitu, eksistensi mereka tetap terjaga dalam pergaulan.

2. Factor penyebab adanya begal motor adalah adanya Industri gadget dan otomotif (sepeda motor),serta balapan liar menjadi sebuah tren yang harus senantiasa diikuti.media, khususnya film serta games. Saat ini baik film, sinetron, ataupun permainan banyak yang menampilkan adegan kekerasan secara vulgar yang seolah mengajari penontonnya untuk bisa melakukan hal tersebut.lemahnya pengawasan 
sosial. Satu sama lain saat ini kurang peduli.Sistem keamanan seperti ronda juga sudah jarang yang melakukannya.kondisi perekonimian Negara kita masih belum cukup baik. Saat harga kebutuhan pokok meningkat, berbanding terbalik dengan penghasilan.

3. Dampak lain dari maraknya aksi begal motor yang marak belakangan ini.kopdar klub ikut sepi akibat begal motor. Maklum, masyarakat jarang yang mau ambil resiko bepergian di malam hari akhir-akhir ini.Begitu juga pada kegiatan kopdar klub motor, ikut kena imbasnya.

4. Solusinya Jika hendak bepergian, jangan mengendarai motor sendirian. Mintalah orang lain menemani Anda. Jika perlu, ajak orang sekampung ikut Dijamin, begal motor paling koplak sekalipun tak berani membegal Anda.Secarapsikologis, begal lebih suka beraksi di tempat yang sepi dan gelap.

\section{DAFTAR PUSTAKA}

Abdullah, A.W .(1986).Topik-topik masalah sosial Bahan Bacaan Mata Kuliah Ilmu Sosial Dasar.Jakarta: Akademika presindo.

Almond, Hari, (2000). Lingkungan Sosial dalam Perspektif Antropologi Budaya, Yogyakarta: pustaka Pelajar .

Bellami, sinta.(1970).Ilmu teori social moderen . Surabaya: Usaha Nasional.

Blau, Jakobus, (2012). Sistem Sosial masalah sosial, Bogor: Ghalia Indonesia.

Damsar, P.J, (2003). Manunggaling Kaula Gusti Pantheisme dalam Sastra Suluk Jawa, Suatu Studi Filsafat. Jakarta:PT Gramedia.

Damsar, Sinta. (2010) .Pengantar Sosiologi Politik. Jakarta: Kencana Prenada.

Garna, Judistira K. (1996) .Sistem Budaya Indonesia, Bandung: Ghalia Indonesia.

Garna, Judistira. (1996). Ilmu Sosial Budaya. Bandung: Katalog dalam Terbitan.

Koentjaningrat, (2000).Kebudayaan Mentalitas dan Pembangunan, Jakarta: PT.Gramedia Pustaka Utama.

Kadir, P.J, (2005) .Ilmu social budaya dasar, Suatu Studi etika. Jakarta:PT Citra Aditya Bakti.

Poerwanto, Hari, (2000). Kebudayaan dan Lingkungan Sosial dalam Perspektif Antropologi Budaya, Yogyakarta: Pustaka Pelajar (Anggota IKAPI).

Ranjabar, Jakobus, (2012) . Sistem Sosial Suatu Pengantar, Bogor: GhaliaIndonesia. 
Rahman,S.Carr, (2013). A Survey Online Journalist 2013:23, The calm before start (http://id.shvoong.com/social-sciences/sociology/2117687-pengertian-nilaisosial/\#ixzz37fUlKeyZ,di Akses 28 April 2015).

Soekanto, Soerjono. (1982) .Sosiologi Suatu Pengantar.Jakarta : PT. Raja Grafindo Persada.

Setiadi Elly M, Hakam Kama A, dan Effendi Ridwan. (2006). Ilmu Sosial Budaya Dasar. Jakarta: Kencana.

Tilaar, H.J.R, (1999). Pendidikan, Kebudayaan, dan Masyarakat Madani Indonesi, Strategi Reformasi Pendidikan Nasional. Bandung: PT. Remaja Rosdakarya.

Widjadja, A.W .(1986). Topik-topik Kumpulan Bahan Bacaan Mata Kuliah Ilmu Sosial Dasar.Jakarta: Akademika Presindo.

Zoetmulder, P.J,(1990). Manunggaling Kaula Gusti Pantheisme dalam Sastra Suluk Jawa, Suatu Studi Filsafat. Jakarta:PT Gramedia. 